\title{
É possível se criar um "Technological Road Map” de soldagem para o Brasil?
}

Muitas vezes sabemos que precisamos melhorar nossas metodologias de trabalho e/ou processos de produção para acompanhar o mercado cada vez mais competitivo e exigente. Mas o grande problema é saber o que fazer neste sentido. E quando não sabemos, qualquer coisa que venhamos a tentar parece ser saudável e promissor, pois o importante é tentar; se ter a consciência de que não estamos parados. E por fazer sentido para muitos, a abordagem de tentar para ver no que vai dar tem sido trilhada por muitos ex-empresários e ex-agentes no mercado. Esta prática tornou-se frustração para muitos.

E exatamente por isto é que alguns outros passaram a questionar se "tentar por tentar" seja mesmo uma solução inteligente. Planejamento, seja no campo da estratégia ou operacional, parece ser uma atitude indispensável para ajudar as empresas a tomarem decisões na alocação de seus recursos. E uma forma de planejamento que está crescendo de importância é o "Technological Road Map" (TRM). Um TRM não é um planejamento simples, pois procura encontrar o consenso quanto aos objetivos, visão e plano de ação em uma área específica, como por exemplo, a soldagem e operação afins. Em muitos países, através de suas associações de classe civil ou empresarial, um TRM tem sido feito como forma de subsidiar empresas e governantes em seus programas de desenvolvimento. Um TRM pode e deve mostrar e justificar, por exemplo, o grau de automação demandada para os próximos anos em diferentes segmentos e o nível e quantidade necessário e a potencial oferta disponibilizada de pessoal para trabalhar com soldagem. Ou seja, um levantamento realista, com a visão no futuro.

Por isto um TRM não se faz por uma única pessoa fechada num sala de um grande centro empresarial. É feito pelos representes de vários segmentos. Mas mesmo nestes países, e mesmo com o reconhecimento da importância crítica da soldagem na manufatura de produtos e bens de capital, existem barreiras que impedem a plena formulação e implementação de TRM, tais como:

- Os executivos seniores costumam ver a soldagem como commodities ou despesas;

- Os agentes de mercado não têm ou escondem dados verdadeiros de suas atividades e perspectivas;

- Soldagem é um desafio científico e tecnológico não facilmente superado;

• A visão dos estudantes é de que soldagem é "sujo" e de indústria fora de moda;

Mas, o Brasil tem alcançado nos últimos anos a condição mínima para traçar um TRM, já que possui uma infraestrutura moderna na área metal-mecânica, tem boas universidades e alguns grupos de pesquisa, um sistema próprio de qualificação e certificação de soldadores e inspetores e um programa internacionalizado para qualificação de engenheiros de soldagem, podendo atender os preceitos da norma ISO 8340. Precisamos, então, apenas superar os pontos acima referenciados, ato possível pela conscientização do problema entre todos os agentes na indústria metal-mecânica e pela disponibilização de lideranças para:

- Fazer com que os "CEO's", executivos e governantes estejam cientes do papel estratégico da soldagem na manufatura moderna;

- Incorporar as considerações de soldagem e processos afins em estágios iniciais dos projetos dos produtos nos quais soldagens são utilizadas;

- Mostrar o lado moderno e o desafio da soldagem e processos afins, para atrair mais profissionais talentosos para indústria;

- Atualizar e integrar os programas educacionais relacionados à soldagem, para soldadores, técnicos e engenheiros;

- Criar ou inovar arcabouços jurídicos e fiscais que permitam aos servidores públicos dos grupos de pesquisas de universidades públicas atuarem realmente em contato com o meio industrial;

- Criar programas específicos com demanda orientada, fomentados pelos governos e federações das indústrias, para inovação da indústria que utiliza da soldagem;

- Criar programas de inovação com comprometimento da indústria e envolvimento real de pesquisadores;

Desta forma, é possível criar um “Technological Road Map" (TRM) de soldagem para o Brasil, pois é mais uma questão de atitude das pessoas envolvidas do que incapacidade.

\section{Américo Scotti}

*A Welding International contribui para a divulgação de pesquisas feitas na área de soldagem e publicadas em diversos idiomas, traduz para o inglês e publica artigos de revistas parceiras, confiando assim no processo de revisão de cada um de suas parceiras. 